Egyptian Journal of Rabbit Science, 30(1): 23- 41 (2020)

\title{
PRODUCTIVE AND PHYSIOLOGICAL PERFORMANCE OF GROWING RABBITS AS AFFECTED BY PEPPERMINT OIL AND Vitex Agnnus EXTRACT DURING SUMMER SEASON
}

\author{
M.E. El-Speiy ${ }^{1}$, M.M. Abdella ${ }^{1}$, M. A.Abd-Elaal ${ }^{1}$ and Ayman M.Khalifah ${ }^{2}$ \\ ${ }^{1}$ Anim. Prod. Res. Institute, Agric. Res. Cent., Egypt, \\ Livestock Research Department, Arid Land Cultivation Research Institute - \\ City of Scientific Research and Technological Applications, (SRTA-City) \\ ,Alexandria, Egypt. Correspondence: E. mail: Mohamed.elspeiy@yahoo.com.
}

This study was conducted to investigate the effect of Peppermint oil (PO) and/or Vitex Agnnus leaf extract (VALex) supplementations on growth performance of rabbits during summer season. Forty-eight Californian growing male rabbits aged 35 days with initial body weight of $640 \pm 34.7 \mathrm{~g}$ were randomly divided into four equal groups. Rabbits in control group $(C)$ were fed a basal diet without supplementation ( $1^{\text {st }}$ group). The $2^{\text {nd }}, 3^{\text {rd }}$, and $4^{\text {th }}$ groups were fed basal diet supplemented with $800 \mathrm{mg} / \mathrm{kg}$ diet of PO, orally $1 \mathrm{ml}$ VALex $/ \mathrm{kg}$ body weight and $800 \mathrm{mg} / \mathrm{kg}$ diet of PO plus orally 1 $\mathrm{ml}$ VALex / kg body weight, respectively.

Results are summarized as follows:

1- Increasing in final body weight $(B W)$ and average body weight gain $(A B W G)$ for all treated groups with $P O$ and /or VALex compared to control group.

2-Tested supplementationshad insignificant effect on feed intake (FI), while feed conversion ratio (FCR) was significantly improved by $22.66 \%$, $24.7 \%$ and $20.9 \%$ for the treated groups with PO, VALex and their combination groups, respectively, versus the control group.

3- Tested supplementations significantly $(P \leq 0.05)$ improved Pre-slaughter weight with those for control group, while insignificant differences were existed in carcass and edible parts.

4-Supplementationssignificantly decreased blood triglyceride (TG), total cholesterol(TC),high density lipoprotein (HDL) and low density lipoprotein $(L D L)$

to control group, while supplemented groups did not represent any concentrations,alanine and aspartate aminotransferase (AST and ALT) and demeinching malonyaldehyde (MDA), while the groups supplied with 
PO and Vitex Agnnus extract had significantly high total antioxidant capacity (TAC) level compared with those of the control group.

5- Total antibody IgG significantly increased for all supplemented groups with PO and /or VALex compared statistically change inIgM.

Conclusively, it could be recommended that using Peppermint oil and Vitex Agnnus extract could be a good tool for maximizing the growth performance, physiological status and immune response for growing rabbits under summer conditions.

Keywords: Peppermint oils- Vitex Agnnus extract - Rabbits- growth performance- Immune response- Antioxidant status.

High ambient temperature (heat stress) results in a widespreadannual economic casualtyin the animal production due to reductions in feed intake, weight loss, diminishedcarcass quality and attenuateof the immune system's protection. Regulation of body temperature through cardiovascular system changes occur including the balance of acid-base, blood $\mathrm{pH}$, respiratory alkalosis and decreased levels of blood viscosity (increase blood flow) and blood plasma protein concentration (Teeter et al. 1985).

Heat stress leads to immoderate production of free radicals, which diminished total antioxidant capacity (Robert et al. 2003). Actually, heat stress affects the sympathetic nerves and causes catecholamine hormone release thereby leading to a rise in free radicals in the blood and tissues of the body such as malonyaldehyde. Free radicals assaulttheconstructing of unsaturated fat, caused damaging cell membranes (Curiet al., 2003) and increase the peroxidation in cells whereof lead toraise lipoperoxide concentrations in the tissues. Lipoperoxide surplus leads to reduced enzyme activity of glutathione peroxides, superoxide dismutase and catalase (Du et al. 2000). On the other hand, Mashaly et al. (2004) showed thatheat stress also alterationvarious components of the immune system such as killer T-cell activity, cytokines secretion, propagation of lymphocytes and the level of immune proteins in broiler chickens.

Peppermint (Mentha piperita, PO) is a perennialherb belonging to the Lamiaceae family. The oil of $M$. piperita contains 1, 8-cineole, dihydrocavone, limonene, phytol, linalool, thymol, carveol, piperitenone, and eugenol as the primary components (Pudpilaet al., 2011). Moreover, peppermint oil is used to treat respiratory disorders (Nishino et al., 1997), digestive complaints, neuralgia, 
myalgia, headaches, migraines and chicken pox (Blumenthal, 1998), menstrual cramps (Foster and Tyler, 1999), antispasmodic (Leicester et al 1982). Peppermint essential oil also has an antimicrobial effect (Pramila et al., 2012), a hepatoprotective effect due to its antioxidant content and free radical scavenger properties (Khalil et al., 2015).

Vitex (Vitex Agnus cactus L from the family of Verbenaceae) extract have been containing phytomedicinal preparations and used in traditional medicine to treat production and reproduction problems (Lachowicz, et al., 1997). The chemical compounds of Vitex extract contain several active compounds such as alkaloid vitexin, flavanols derivatives, and Kaempferol and quercetin which are excessively composed of casticin (Karunamoorthiet al., 2008). Also, Van Die et al. (2013) resulted that this plant is composed of iridoid glycosides, flavonoids, diterpenes, and volatile oil. Water extracts and ethanolic extracts of Vitex have antioxidant activity because of its flavonoid, diterpenoid, and ecdysteroid content (Chaoucheet al.,2014)and modulates the activities of superoxide dismutase (SOD), catalase (CAT) and glutathione peroxides (Liuet al., 2004).

Therefore, the objective of the present study was to investigate the effects of Peppermint (OP), Vitex Agnus cactus leaves (AAL) and its combination on the growth performance, carcass traits, blood biochemistry, antioxidant and immune status of growing rabbits.

\section{MATERIALS AND METHODS}

\section{Housing and Management:}

The present study was carried out at a Private rabbit farm in Alexandria Governorate during summer season.Ambient temperature ranged from 29 to $32^{\circ} \mathrm{C}$ while, relative humidity ranged from 45 to $58 \%$ and light photo period $16 \mathrm{hr}$. light: $8 \mathrm{hr}$. dark.

Animals were kept in clean, separate wire-floor metal cages $(50 \mathrm{~cm}$ length $\times$ $45 \mathrm{~cm}$ width $\times 40 \mathrm{~cm}$ high) and maintained under standard laboratory conditions and kept the same managerial conditions, healthy, hygienic and clinically free of external and internal parasites.

\section{Aqueous extract of Vitex agnus leaf (VALex):}

Weight dried $100 \mathrm{mg} / \mathrm{kg}$ of leaf of Vitex agnus, then grinded into fine powder and mixed with 10 milliliter of boiled distilled water and let for 10 minutes.After that, the crude extract was filtrate by Whatman No.1 paper and 
evaporator the crude extract by water stemat 20 minutesthen concentrated solution using water vapor. The crude extract was stored at glass bottles with tight lids in a refrigerator in moisture-free conditions until used in the study (each $1 \mathrm{ml}$ contained100mg of VALex) (Hussein, 2007).

Assessment of effective compounds by HPLC according to Dogan et al. (2011). Analysis of Plant Oils:

Table 1.

The major important components of PO oil and VALex are presented in

Table 1: Some chemical properties of Peppermint oil $(P O)$ and aqueous extract of Vitex agnus castus leaf (VALex)

\begin{tabular}{|l|c|c|}
\hline Qualitative compounds & Peppermint oil & $\begin{array}{l}\text { Aqueous extract of Vitex agnus } \\
\text { castus(VALex) }\end{array}$ \\
\hline Pulegone & $43.5 \%$ & $====$ \\
\hline Piperitone & $12.2 \%$ & $====$ \\
\hline P-menthane-1,2,3-trioe & $6.5 \%$ & $====$ \\
\hline$\gamma$-elemenene $(3.6 \%)$, & $3.6 \%$ & $====$ \\
\hline Guaieene (cis- $\beta$ ) & $3 \%$ & $====$ \\
\hline Carvacerol acetate & $2.6 \%$ & $====$ \\
\hline Phenyl ethyl alcohol & $2.4 \%$ & $42.3437(\mu \mathrm{g} / \mathrm{g})$ \\
\hline Isovitexin & $====$ & $23 ., 852(\mu \mathrm{g} / \mathrm{g}$ \\
\hline Casticin & $====$ & \\
\hline
\end{tabular}

Aqueous extract of vitexagnus castus analysis according to Dogan et al. (2011).Peppermint analysis according to Ahmed (2006)

\section{Diet nutrient profiles:}

Feed and drinking water were offered on ad libitum basis. All rabbits were fed the same basal diet formulated according to the nutritional requirements of the National Research Council (NRC, 1977), which ingredients and calculated chemical composition are displayed in Table 2.

\section{Experimental design:}

A total number of 48 male California growing rabbits(weaned) aged 35 days with initial body weight of $640 \pm 34.7 \mathrm{~g}$ were randomly divided into four equal treatment groups (12 males per each). The experiment lasted for 7 weeks; the groups were submitted to different experimental dietary treatments as follows: 
Table 2: The basal diet formulated ingredient composition and chemical analysis of the experimental diet

\begin{tabular}{|c|c|c|c|c|c|}
\hline Ingredients & Kg/ton & \multicolumn{4}{|c|}{ Calculated analysis } \\
\hline Clover hay & 395 & \multicolumn{3}{|c|}{ Crude protein, $\%$} & 16.8 \\
\hline Soybean meal & 175 & \multicolumn{3}{|c|}{ Crude fiber, $\%$} & 13.7 \\
\hline Wheat bran & 149 & \multicolumn{3}{|c|}{ Ether extract, \% } & 3.0 \\
\hline Barley & 130 & \multicolumn{3}{|c|}{ Digestible energy (kcal/kgdiet) } & 2680 \\
\hline Yellow corn & 100 & \multicolumn{3}{|c|}{ n-6 PUFAs $\%$} & 0.3 \\
\hline Molasses & 30 & \multicolumn{3}{|c|}{ n-3 PUFAs\% } & 1.03 \\
\hline Dicalcium phosphate & 8 & \multicolumn{4}{|c|}{ Determined analysis $(\mathrm{g} / \mathrm{kg})$} \\
\hline Limestone & 5 & $\overline{\mathrm{DM}}$ & 897.1 & $\mathrm{CF}$ & 138.5 \\
\hline Sodium chloride & 2 & $\mathrm{OM}$ & 801.4 & $\mathrm{EE}$ & 23.7 \\
\hline Vit. + Min. Premix & 3 & $\mathrm{CP}$ & 169.8 & NFE & 575.0 \\
\hline DL-Methionine & 3 & \# & \# & Ash & 96.9 \\
\hline
\end{tabular}

*Provides per kg of diet: Vit. A 6000 IU; Vit. D 450 IU; Vit.E 40 mg; Vit. K 1mg; Vit. B1 1mg; Vit. B2 3 mg; Vit. B3 $180 \mathrm{mg}$; Vit. B6 39 mg; Folic acid $2.5 \mathrm{mg}$; Vit. B12 $5 \mu \mathrm{g}$; Pantothenic acid 10 mg; Biotin $10 \mu \mathrm{g}$; Choline Chloride $1200 \mathrm{mg}$; Zn 35 mg; Fe 38 mg; Cu 5 mg; I 0.2 mg; Se $0.05 \mathrm{mg}$ and $\mathrm{Mn} 15 \mathrm{mg}$.

DM: Dry matter, OM: Organic matter, CP: Crude protein, CF: Crude fiber, EE: Ether extract, NFE: Nitrogen-free extract,

Group 1: Feed basal diet and served as control.

Group 2: Feed basal diet mixed with $800 \mathrm{mg} \mathrm{PO} / \mathrm{kg}$ diet.

Group 3: Feed basal diet + orally $1 \mathrm{ml} \mathrm{VALex/} \mathrm{kg} \mathrm{BW}$.

Group 4: Feed basal diet +800 mg PO/kg diet + orally $1 \mathrm{ml} \mathrm{VALex/} \mathrm{kg} \mathrm{BW.}$

\section{Growth performance traits:}

The average daily gain (ADG) was calculated on a group basis as follows: $\mathrm{ADG}=$ (final live $\mathrm{BW}$ - initial live $\mathrm{BW}$ during a certain period $) /$ number of days for this period. Feed intake (FI) was calculated as the difference between the weight of the feed offered and the weight of the remained at same day of weighing the animals. Feed conversion (FC) ratio was computed as the ratio between feed intake and weight gain per period.

\section{Carcass characteristics:}

At the end of the experimental growing period, six rabbits were selected around the average of each treatment for carcass evaluations. The rabbits were fasted with a free water supply for $12 \mathrm{~h}$ before slaughtering. The rabbits were weighed pre-slaughter, slaughtered for complete depletion, skinned, and 
eviscerated. The dressed carcass free from any internal organs was weighed (carcass weight without the head). The eviscerated carcass included liver, heart and kidney were weighed. The carcass yields were calculated as a percentage of the pre-slaughter live initial body weight of the rabbits. Additionally the percentages of the total edible parts and giblets were calculated as follows:

Giblets $\%=$ Kidney $\%+$ Heart $\%+$ Liver $\%$,

Total edible parts $\%=$ Carcass $\%+$ Kidney $\%+$ Heart $\%+$ Liver $\% .+$ Lung $\%$ .(Sabrin et al., 2019).

\section{Blood biochemical and serum metabolites:}

The blood samples were withdrawn at morning from marginal ear veins under vacuum in clean tubes without heparin for each treatment group before access feed and water. Serum was obtained by centrifugation the blood at 4000 rpm for $20 \mathrm{~min}$ for analysis the blood biochemical parameters (total plasma protein, albumin, globulin was calculated ,cholesterol, aspartate aminotransferase, alanine aminotransferase, triglycerides (TG), high-density lipoprotein (HDL), low-density lipoprotein (LDL) and malonyaldehyde (MAD), total antioxidant capacity (TAC).

All biochemical parameters were analyzed by commercially available kit methods. GNW-Model: SM-721Spectrophotometers, Absorbance Microplate Reader and other laboratory equipment aids were used for biochemical analysis. Moreover, each parameter was done according to the instructions of its kit.

\section{Immune Response:}

Different types of immunoglobulins in blood serum (IgG and $\operatorname{IgM}$ ) were determined using commercial ELISA kits (Kamiya Biomedical Company, USA).

\section{Statistical Analysis:}

All data were subjected to analysis of variance according to the statistical analysis system (SAS, 2002). The differences among groups means were tested by using Duncan's multiple rang test (Duncan, 1955).

\section{Growth Performance:}

\section{RESULTS AND DISCUSSION}

Effect of PO, VALex and their combination supplementation on the growth performance of growing California male rabbits are shown in Table 3 . The experimental supplementations significantly $(\mathrm{P} \leq 0.05)$ increased the final $\mathrm{BW}$, 
Table 3: Effect of dietary supplemented with peppermint oil (PO), oral administrated aqueous extract of vitex agnus leaf (VALex) and their combination on growth performance of growing male rabbits during summer season

\begin{tabular}{|l|c|c|c|c|}
\hline \multicolumn{1}{|c|}{ Items } & Control & $\begin{array}{c}\text { PO 800 } \\
\mathbf{m g} / \mathbf{k g ~ d i e t}\end{array}$ & $\begin{array}{c}\text { Orally 100 mg/ } \\
\text { kg BW VALex }\end{array}$ & $\begin{array}{c}\text { PO 800 mg/kg diet + } \\
\text { orally 100 mg/ kg BW } \\
\text { VALex }\end{array}$ \\
\hline Initial BW, g & 635 & 632 & 640 & 625 \\
& \pm 36.3 & \pm 37.8 & \pm 34.7 & \pm 25.2 \\
\hline Final BW, g & $1700^{\mathrm{b}}$ & $1950^{\mathrm{a}}$ & $2006^{\mathrm{a}}$ & $2000^{\mathrm{a}}$ \\
& \pm 46.5 & \pm 34.3 & \pm 29.8 & \pm 25.8 \\
\hline ADG, g/ & $21.73^{\mathrm{b}}$ & $26.9^{\mathrm{a}}$ & $27.88^{\mathrm{a}}$ & $28.06^{\mathrm{a}}$ \\
rabbit/day & \pm 0.94 & \pm 1.21 & \pm 1.10 & \pm 0.99 \\
\hline FI, g/ & 135.31 & 129.38 & 130.10 & 132.00 \\
rabbit/day & \pm 4.5 & \pm 2.87 & \pm 3.66 & \pm 3.42 \\
\hline FCR & $6.22^{\mathrm{a}}$ & $4.81^{\mathrm{b}}$ & $4.68^{\mathrm{b}}$ & $4.70^{\mathrm{b}}$ \\
& \pm 0.45 & \pm 0.39 & \pm 0.62 & \pm 0.44 \\
\hline
\end{tabular}

${ }^{\mathrm{a}-\mathrm{b}}$ : Values in the same row with different superscripts differ significantly $(\mathrm{P} \leq 0.05)$.

BW: body weight, $\mathrm{ADG}=$ average daily gain, $\mathrm{FI}=$ feed intake, $\mathrm{FCR}=$ feed conversion ratio.

ADG and improved FCR of the California growing rabbits during the experimental period compared with those in for control group. Feed intake was not statistically changed.

The improvement in FCR reached $22.66 \%, 24.7 \%$ and $20.9 \%$ for the groups supplied with PO, VALex and their combination, respectively compared with the control group.

Improvement results obtained due to supplying growing rabbit's diets with PO oil, oral VALex and their combination were coincided with the results reported by Arab Ameri et al. (2016) who demonstrated that consumed peppermint powder significantly improved feed conversion ratio and body weight. Same results obtained by Galib and Al-Kassi (2010) whoshowed that anamelioration in BWG and FCR under dietary treatment with peppermint powder. Otherwise, Helander et al. (1998) argued that the antimicrobial activity compounds present in peppermint, increased growth, appetite and BW by restricting the growth of harmful microorganisms. Counteractively, Sabrinet al. (2019) reported the supplemented diet with PO (400mg/ $/ \mathrm{kg}$ diet) did not 
significantly affect the final live body weight and average daily gain compared with the control.

Same results obtained by Akbari and Torki (2014) who showed that the average BW, ADG and daily FI in female broiler chicks did not significantly affected by dietary supplementation with PO.

On the other hand, regarding $V$. agnus-castusthisplant has well-known biological potential on digestive, antifungal and aperitif (Regianeet al., 2017). Also, Ekundayoet al. (1990) recordedthat the essential oils from different parts of $V$. agnus-castushave been reported to display antibacterial activity against Escherichia coli, Pseudomonas aeruginosa, Bacillus subtilis, and Staphylococcus aureus, so led to increased growth, appetite and BW.

In same context, V. agnus-castus leaves and fruits contained several major classes of phytoconstituents (Lee et al., 2017). Photochemical have been shown to exert their positive antioxidant benefits toward animals interms of favored performance, production quality (Ansari et al., 2012) and enhanced indirectly as stabilized conjugates affecting metabolic pathway (Aggarwal and Shishodia, 2006).

\section{Carcass traits:}

Date of Table 4 presents the effects of the PO, VALex and their combination on carcass characteristics. All treatment groups represented significant $(\mathrm{P} \leq 0.05)$ improvement in Pre-slaughter weight compared with control.

The rest parameters of carcass such as hot carcass, liver, heart, kidney and lung did not reveal any statistical change among the experimental groups.In agreement with the present results, Abdel-Wahab et al. (2018) display that all carcass parameters of quails were not significant affected due to peppermint supplementation. Also, Khempaka et al. (2013) showed that the percentages of eviscerated carcasses and giblets of broilers consumed dried peppermint containing diets $(0.5-2.0 \%)$ were identical to those in the control group. Same result obtained by Ocak et al. (2008) who reported that broiler diet supplemented with dry peppermint had not significant effect on the relative weights of the whole gut, pancreas and edible inner organs, at slaughter. In contrast, dietary supplementation with peppermint resulted in a decreasing trend in the carcass percentages of growing Japanese quail (Mehri et al., 2015a).

However, supplemented diet with PO led to significant improvement of pre-slaughter weight (Arab Ameri et al., 2016). Concerning, Vitex agnus castus, limited information is available in effect on carcass traits. 
Table 4: Effect of dietary supplemented with peppermint oil (PO), oral administrated aqueous extract of vitexa gnus leaf (VALex) and their combination on carcass traits of growing male rabbits during summer season

\begin{tabular}{|c|c|c|c|c|}
\hline Items & Control & $\begin{array}{c}\text { PO, } 800 \\
\text { mg/kg diet }\end{array}$ & $\begin{array}{c}\text { VALex, orally } \\
100 \mathrm{mg} / \mathrm{kg} \\
\text { BW }\end{array}$ & $\begin{array}{c}\text { PO } 800 \mathrm{mg} / \mathrm{kg} \\
\text { diet + orally } 100 \\
\text { mg/ kg } \\
\text { BW,VALex }\end{array}$ \\
\hline $\begin{array}{l}\text { Pre-slaughter } \\
\text { weight, g }\end{array}$ & $\begin{array}{c}1853.33^{\mathrm{b}} \\
\pm 21.32 \\
\end{array}$ & $\begin{array}{c}2161.66^{\mathrm{a}} \\
\pm 35.41 \\
\end{array}$ & $\begin{array}{c}2210.33^{\mathrm{a}} \\
\pm 25.61\end{array}$ & $\begin{array}{c}2225.01^{\mathrm{a}} \\
\pm 31.22\end{array}$ \\
\hline Hot carcass, $\%$ & $\begin{array}{l}53.51 \\
\pm 2.12 \\
\end{array}$ & $\begin{array}{l}55.51 \\
\pm 2.45 \\
\end{array}$ & $\begin{array}{l}56.19 \\
\pm 3.12 \\
\end{array}$ & $\begin{array}{l}54.16 \\
\pm 2.11 \\
\end{array}$ \\
\hline Liver, \% & $\begin{array}{c}3.8 \\
\pm 0.74 \\
\end{array}$ & $\begin{array}{c}3.42 \\
\pm 0.65 \\
\end{array}$ & $\begin{array}{c}3.39 \\
\pm 0.42 \\
\end{array}$ & $\begin{array}{c}3.44 \\
\pm 0.39 \\
\end{array}$ \\
\hline Heart, \% & $\begin{array}{c}0.33 \\
\pm 0.06 \\
\end{array}$ & $\begin{array}{c}0.32 \\
\pm 0.03 \\
\end{array}$ & $\begin{array}{c}0.30 \\
\pm 0.32\end{array}$ & $\begin{array}{c}0.35 \\
\pm 0.04\end{array}$ \\
\hline Kidneys, \% & $\begin{array}{c}0.59 \\
\pm 0.03 \\
\end{array}$ & $\begin{array}{r}0.56 \\
\pm 0.07 \\
\end{array}$ & $\begin{array}{c}0.53 \\
\pm 0.02 \\
\end{array}$ & $\begin{array}{c}0.56 \\
\pm 0.06 \\
\end{array}$ \\
\hline Lung, \% & $\begin{array}{c}0.73 \\
\pm 0.07\end{array}$ & $\begin{array}{c}0.70 \\
\pm 0.09\end{array}$ & $\begin{array}{c}0.73 \\
\pm 0.04\end{array}$ & $\begin{array}{c}0.65 \\
\pm 0.08\end{array}$ \\
\hline Giblets $^{1}, \%$ & $\begin{array}{c}4.72 \\
\pm 0.67\end{array}$ & $\begin{array}{c}5.00 \\
\pm 0.46 \\
\end{array}$ & $\begin{array}{r}4.95 \\
\pm 0.59 \\
\end{array}$ & $\begin{array}{c}5.00 \\
\pm 0.46 \\
\end{array}$ \\
\hline $\begin{array}{l}\text { Total edible } \\
\text { parts }^{2}, \%\end{array}$ & $\begin{array}{l}58.23 \\
\pm 2.27 \\
\end{array}$ & $\begin{array}{l}60.51 \\
\pm 1.88 \\
\end{array}$ & $\begin{array}{l}61.04 \\
\pm 3.16 \\
\end{array}$ & $\begin{array}{l}59.16 \\
\pm 1.88 \\
\end{array}$ \\
\hline
\end{tabular}

${ }^{\mathrm{a}-\mathrm{b}}$ : Values in the same row with different superscripts differ significantly $(\mathrm{P} \leq 0.05)$. Giblets ${ }^{1} \%=$ Kidney $\%+$ Heart $\%+$ Liver $\%+$ Lung $\%$. Total edible parts ${ }^{2} \%=$ Hot carcass $\%+$ Kidney\%+ Heart\%+Liver\%.

Serum Lipid Profile, Antioxidant Status, Biochemical Blood and Immune Response:

Data in Table 5 show the effects of PO, VALex supplementations and their combination between them on serum lipid profile and antioxidant status. In the present study, the experimental treatments had a significant $(\mathrm{P} \leq 0.05)$ improvement in the blood serum total cholesterol, triglyceride, HDL and LDL levels compared with those of the control group. Moreover, data showed that growing rabbits reared during the Egyptian summer season exhibited significant $(\mathrm{P} \leq 0.05)$ decrease in serum TAC based on the results obtained for the control group, whereas the PO, VALex and their combination supplementation significantly $(\mathrm{P} \leq 0.05)$ ameliorated the effect of stress during summer season, decreasing serum MDA concentration 
Table 5: Effect of dietary supplemented with peppermint oil (PO), oral administrated aqueous extract of vitex agnus leaf (VALex) and their combination on serum lipid profile and antioxidant status of growing male rabbits during summer season

\begin{tabular}{|l|c|c|c|c|}
\hline \multicolumn{1}{|c|}{ Items } & Control & $\begin{array}{c}\text { PO 800 } \\
\text { mg/kg diet }\end{array}$ & $\begin{array}{c}\text { orally 100 } \\
\text { mg/ kg BW } \\
\text { VALex }\end{array}$ & $\begin{array}{c}\text { PO 800 mg/kg diet } \\
+ \text { orally 100 mg/ } \\
\text { kg BW VALex }\end{array}$ \\
\hline TG, $\mathrm{mg} / \mathrm{dL}$ & $94.80^{\mathrm{a}}$ & $72.13^{\mathrm{bc}}$ & $78.13^{\mathrm{b}}$ & $75.84^{\mathrm{b}}$ \\
& \pm 4.24 & \pm 12.21 & \pm 2.83 & \pm 2.33 \\
\hline $\mathrm{TC}, \mathrm{mg} / \mathrm{dL}$ & $82.57^{\mathrm{a}}$ & $74.30^{\mathrm{b}}$ & $71.24^{\mathrm{b}}$ & $73.44^{\mathrm{b}}$ \\
& \pm 10.40 & \pm 6.57 & \pm 2.57 & \pm 2.17 \\
\hline HDLmg/dL & $34.62^{\mathrm{c}}$ & $41.62^{\mathrm{a}}$ & $39.51^{\mathrm{a}}$ & $41.72^{\mathrm{a}}$ \\
& \pm 0.67 & \pm 0.88 & \pm 1.31 & \pm 0.88 \\
\hline LDL $\mathrm{mg} / \mathrm{dL}$ & $42.15^{\mathrm{a}}$ & $33.55^{\mathrm{b}}$ & $31.62^{\mathrm{b}}$ & $30.92^{\mathrm{b}}$ \\
& \pm 1.06 & \pm 1.21 & \pm 1.40 & \pm 1.40 \\
\hline TAC, $\mu \mathrm{mol} / \mathrm{ml}$ & $1.26^{\mathrm{c}}$ & $1.63^{\mathrm{ab}}$ & $1.65^{\mathrm{ab}}$ & $1.87^{\mathrm{a}}$ \\
& \pm 0.06 & \pm 0.11 & \pm 0.44 & \pm 0.12 \\
\hline MDA, nmol/ml & $6.04^{\mathrm{a}}$ & $4.83^{\mathrm{b}}$ & $5.17^{\mathrm{b}}$ & $4.98^{\mathrm{b}}$ \\
& \pm 0.28 & \pm 0.42 & \pm 0.78 & \pm 0.65 \\
\hline
\end{tabular}

a-b-c: Values in the same row with different superscripts differ significantly $(\mathrm{P} \leq 0.05)$. $\mathrm{TG}=$ Triglyceride, $\mathrm{TC}=$ total cholesterol, $\mathrm{HDL}=$ high density lipoprotein, $\mathrm{LDL}=$ low density lipoprotein, $\mathrm{IgG}=$ immunoglobulin $\mathrm{G}, \mathrm{IgM}=$ immunoglobulin $\mathrm{M}, \mathrm{TAC}=$ total antioxidant capacity, MDA= malondialdehyde.

and significantly $(\mathrm{P} \leq 0.05)$ improved TAC for groups supplied with the $\mathrm{PO}$ oil and AEVex compared with that of the control group. These results are consistent with those of Ghazaghi et al. (2014) who showed that consumed peppermint supplementation resulted in a diminishing in the LDL concentration in growing quail. Also, Abdel-wahab et al. (2018) reported that the triglyceride, total cholesterol and LDL concentrations decreased in birds that supplemented dietary peppermint. Additionally, Barbalho et al. (2009) confirm our results and represented that the supplementation of peppermint extract improves plasma lipids profile in mice such as significantly decreases triglycerides, total cholesterol, LDLcholesterol, VLDL-cholesterol and increases HDL-cholesterol in blood serum. On the other hand, Akbari and Torki (2014) documented that the serum total cholesterol, HDL and LDL levels in female broiler chicks had not been affected by dietary supplementation with the PO. 
Concerning, Mentha piperita (EO) possesses antiradical activity with treat with deep respect to DPPH (2,2-diphenyl-1-picrylhydrazyl), and hydroxyl $\left(\mathrm{OH}^{-}\right)$ radicals; actually, Schmidt et al.(2009)who revealed the antiradical activity of this EO for DPPH such as(IC50). Furthermore, Ferreira et al. (2014) reported that M. piperita is associated with rise levels of intracellular ROS, which is indicative of an apoptotic process without the loss of the plasma membrane integrity.

Regarding effect of VALex on lipid profile, Ahmed et al. (2015) reported that vitex agnus castus extracts, led to significant decreased TC, TG and LDL and increase HDL in mice. Same result obtained by Berrani et al. (2018) who showed an improvement in the lipide profile due to oral administration of methanolicextract of Vitex agnus.

Concerning, Vitex agnus castus plays major role on antioxidant capacity, Loch et al. (2000) mentioned that the methanolic extract of $V$. agnus-castus leaves exhibited major antioxidant activity in different antioxidant type, including ferricchelating, scavenging activity of hydrogen peroxideand cupric-reducing antioxidant capacity, Additionally, it is owned several active materials as flavonoids, castein, orientin and which isovitexin possess the antioxidant and radical scavenging properties (Sarikurkcuv et al., 2009). Interestingly, Özlem et al. (2013) illustrated thatcrude extracts of V. agnus-castus seeds have potent antioxidant, cytotoxic and apoptotic activity and reinstatement of activities of some antioxidant enzymes and reduction in the mitochondrial hydrogen peroxide production in animals therapeutic treated with the extract (Moreno et al.,2015).

Data in Table 6 display that the levels of serum total protein, albumin and globulin are significantly $(\mathrm{P}<0.05)$ increased for the rabbit groups supplied with VALex and the combination between VALex and PO compared with that of control group. Moreover, rabbits of the supplemented groups with VALex lonely or combination between VALex and PO represented significant improvement of liver function as induction of the significant reduction of AST and ALT enzymes and improvement synthesis globulin and albumen for these groups compared with control. Besides, the growing rabbits consumed a diet supplemented with PO and VALex had significant $(\mathrm{P}<0.05)$ higher total antibody IgG antibodies compared to control group, while titer IgM did no represented any statistical change among all experimental groups. For fore mentioned results, it is apparent the important role of peppermint for dominant the liver function.

Such findings of total protein, albumin and globulin are in harmony with that previously by Fallah et al. (2013) who mentioned that peppermint had 
Table 6: Effect of dietary supplemented with peppermint oil (PO), oral administrated aqueous extract of vitex agnus leaf (VALex) and theira combination on the serum biochemical and immune response of growing male rabbits during summer season.

\begin{tabular}{|l|c|c|c|c|}
\hline \multicolumn{1}{|c|}{ Items } & Control & $\begin{array}{c}\text { PO 800 } \\
\text { mg/kg diet }\end{array}$ & $\begin{array}{c}\text { orally 100 } \\
\text { mg/ kg BW } \\
\text { VALex }\end{array}$ & $\begin{array}{c}\text { PO 800 mg/kg diet + } \\
\text { orally 100 mg/ kg BW } \\
\text { VALex }\end{array}$ \\
\hline $\mathrm{TP}(\mathrm{g} / \mathrm{dL})$ & $6.34^{\mathrm{b}}$ & $6.56^{\mathrm{b}}$ & $7.54^{\mathrm{a}}$ & $7.15^{\mathrm{a}}$ \\
& \pm 0.32 & \pm 0.41 & \pm 0.44 & \pm 0.34 \\
\hline $\mathrm{ALb}(\mathrm{g} / \mathrm{dl})$ & $3.61^{\mathrm{b}}$ & $3.74^{\mathrm{b}}$ & $4.12^{\mathrm{a}}$ & $4.03^{\mathrm{a}}$ \\
& \pm 0.31 & \pm 0.61 & \pm 0.31 & \pm 0.33 \\
\hline $\mathrm{GLO}(\mathrm{g} / \mathrm{dl})$ & $2.73^{\mathrm{b}}$ & $2.82^{\mathrm{b}}$ & $3.42^{\mathrm{a}}$ & $3.12^{\mathrm{a}}$ \\
& \pm 0.25 & \pm 0.45 & \pm 0.45 & \pm 0.36 \\
\hline $\mathrm{AST}(\mathrm{U} / \mathrm{L})$ & $40.26^{\mathrm{a}}$ & $33.21^{\mathrm{b}}$ & $36.21^{\mathrm{b}}$ & $35.41^{\mathrm{b}}$ \\
& \pm 2.45 & \pm 0.12 & \pm 1.45 & \pm 1.23 \\
\hline $\mathrm{ALT}(\mathrm{U} / \mathrm{L})$ & $30.42^{\mathrm{a}}$ & $27.45^{\mathrm{b}}$ & $25.35^{\mathrm{b}}$ & $26.44^{\mathrm{b}}$ \\
& \pm 1.87 & \pm 0.33 & \pm 1.65 & \pm 2.12 \\
\hline IgG, mg/dl & $198.13^{\mathrm{ab}}$ & $216.17^{\mathrm{a}}$ & $205.57^{\mathrm{a}}$ & $210.13^{\mathrm{a}}$ \\
& \pm 35.85 & \pm 29.82 & \pm 29.82 & \pm 24.87 \\
\hline IgM, mg/dl & 59.43 & 61.89 & 58.39 & 61.11 \\
& \pm 9.57 & \pm 13.03 & \pm 13.03 & \pm 10.13 \\
\hline
\end{tabular}

${ }^{a-b}$ : Values in the same row with different superscripts differ significantly $(\mathrm{P} \leq 0.05)$. $\mathrm{ALT}=$ alanine minotransferase,$\quad \mathrm{AST}=$ aspartate aminotransferase.,$\quad \mathrm{TP}=$ Total protein, Alb =Albumen, $\mathrm{GLO}=$ Globulin, $\mathrm{IgG}=$ Immunoglobulin $\mathrm{G}, \quad \mathrm{IgM}=$ Immunoglobulin M,

increased albumin, total protein in broilers.

Concerning immune response, Awaad et al. (2010) found that the addition of $0.25 \mathrm{~mL}$ of PO on drinking water raise the antibody titer against the Newcastle virus vaccine in chickens. Recently, Abdel-Wahab et al. (2018) stated that IgG, IgA and IgM in quails are increased significantly with peppermint supplementation. On another side, the results of immune response in this study completely confirmed those of El-naggar and El-Tahawy (2018) that broiler supplemented with peppermint had higher IgG.

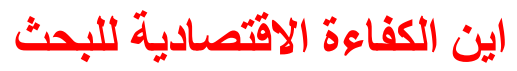


Conclusively, using Peppermint oil and Vitex Agnnus extract could be a good tool for maximizing the growth performance, antioxidant status and immune response for growing rabbits under summer conditions.

\section{REFERENCES}

Abdel-Wahab, A.; Abdel-Kader, I. and Ahmad, E. A., 2018. Evaluation of dried peppermint leaves as natural growth promoters alternative to antibiotics on Japanese quail. Egypt. Poult. Sci., J. , 38.:943-958

Aggarwal ,BB. and Shishodia, S., 2006 .Molecular targets of dietary agents for prevention and therapy of cancer. Biochem Pharmacol.; 71:1397-421.

Ahmed, R. A.; Hayder, B. S.and Saba, N. A.,2015.Anti-hyperlipidemic effect of Vitex agnus castusextracts in Mice. Int. J. Pharm. Sci. Rev. Res., 35(2), Article No. 23, Pages: 120-125.

Akbari, M. and Torki, M., 2014. Effects of dietary chromium picolinate and peppermint essential oil on growth performance and blood biochemical parameters of broiler chicks reared under heat stress conditions. Int. J. Biometeorol., 58: 1383-1391.

Arab, Ameri .S.; Samadi1, F.; Dastar and Zerehdaran ,S. B., 2016. Effect of Peppermint (Mentha piperita) Powder on Immune Respon se of Broiler Chickens in Heat Stress . Iranian J. of Appl. Anim. Sci., 6(2), 435-445

Ansari, J.; Khan, SH.; Haq, Au.; Yousaf, M.,.2012 .Effect of the levels of Azadirachtaindica dried leaf meal as phytogenic feed additive on the growth performance and haemato-biochemical parameters in broiler chicks. J. Appl. Anim.Res. ; 40:336-45.

Awaad, M.; Abdel-Alim, G.; Sayed, K.; Ahmed, A.; Nada, A.; Metwalli, A. and Alkhalaf, A., 2010. Immunostimulant effects of essential oils of peppermint and eucalyptus in chickens. Pak. Vet. J., 30: 61-66.

Barbalho, S.M.; Machado, S.A.P.; Oliveira, E.P.; Pavia-Filho, M.E.; Martuchi, K.A.; Leite, N.C.; Deus, R.M.; Sasaki, V.; Barganti, L.S. and Oshiiwa, M. 2009. Mentha piperita effects on Wistar rats plasma lipids. Int. J. Br. Arch. Biol. Technol., 52(5), 1137-1143. 
Berrani, A. ; Lrhorfi, L.A ; Larbi,O.M. ; El Hessn, A. ; Zouarhi , M. ; Erahali,D. and Bengueddour,R.,H .2018. Hypoglycemic Effect of Vitex agnus castus extract in diabetic rats induced by streptozotocinphy tothérapie, Agriculture Research Communicaton,16: S40-S47.

Blumenthal, M., 1998. Lavender Flower. The complete German Commission E monographs: Therapeutic guide to herbal medicine. Austin: American Botanical Council.

Chaouche, TM; Haddouchi, F.; Ksouri, R. and Atik-Bekkara, F.2014.Evaluation of antioxidant activity of hydromethanolic extracts of some medicinal species from South Algeria. J. Chin Med Assoc 2014; 77:302e7

Curi, R.; Newsholme, P.; Lima, M.M.R.; Pithon-Curi, T.C. and Procopio, J., 2003. Glutamine and glutamate-their central role in cell metabolism and function. Cell. Biochem. Func. 21, 1-9.

Du R., Lin, H. and Zhang, Z.Y., 2000. Peroxide status in tissues of heat stressed broilers. Anim. Sci., 10, 1373-1376.

Duncan, D.B., 1955. Multiple range and multiple F tests. Biometrics, 11: 1-42.

Ekundayo, O. L.; Holopainen, M.; Hiltunen, R.; Oguntimein, B. and Kauppinen, V., 1990. The chemical composition and antimicrobial activity of the leaf oil of Vitex agnus-castus L. J. Essent. Oil Res., 2: 115-119.

El-naggar, A. S. and El-Tahawy, W. ,2018. Productive performance, physiological and immunological response of broiler chicks as affected by dietary aromatic plants and their essential oils. Egypt. Poult. Sci. J., 38:773-792.

Fallah R.; Kiani, A. and Azarfar, A. ,2013. Effect of artichoke levels meal and Mentha piperita extract on immune cells and blood biochemical parameters of broilers. Glob. Vet. 10(1), 99-102.

Ferreira, P.; Cardoso, T.; Ferreira, F.; Fernandes-Ferreira, M.; Piper, P. and Sousa, M.J. ,2014 .Mentha piperita essential oil induces apoptosis in yeast associated with both cytosolic and mitochondrial ROS-mediated damage. FEMS Yeast Res. 14, 1006-1014. [Cross Ref] [PubMed]

Foster, S. and Tyler, V. E., 1999.Tyler's the honest herbal: a sensible guide to the use of herbs and related remedies. (4 $4^{\text {th }}$ Edition) 1 st Edition. Text book, Medicine \% Health Science. 
Galib, M. and Al-Kassi, M.W. ,2010. A comparative study on diet supplementation with a mixture of herbal plants and dandelion as a source of probiotices on the performance of broilers. Pakistan. Int. J. 9(1), 67-71.

Ghazaghi, M.; Mehri, M. and Bagherzadeh-Kasmani, F. ,2014. Effects of dietary Mentha spicata on performance, blood metabolites, meat quality and microbial ecosystem of small intestine in growing Japanese quail. Anim. Feed Sci., Technol., 194: 89-98.

Helander; Alakomi. H.; Latva-Kala, K.; Mattila-Sandholm ,T.; Pol ,I.; Smid, E.; Gorris, L. and Von Wright, A., 1998. Characterization of the action of selected essential oil components on gram negative bacteria. J. Agric. Food Chem. 46, 3590-3595.

Hussein, M. A., 2007. Effect of Vitex agnus-castus extract on some physiological parameters of Mice (Mus Musculus L.). The Med. J. of Basrah University. 25 (2):57-59.

Karunamoorthi, K.; Ramanujam, S. and Rathinasamy, R., 2008 .Evaluation of leaf extracts of Vitex negundo L. (Family: Verbenaceae) against larvae of Culex tritaeniorhynchus and repellent activity on adult vector mosquitoes. Parasitol Res.; 103(3), 545-550.

Khempaka, S.; Pudpila, U. and Molee, W., 2013. Effect of dried peppermint (Mentha cordifolia) on growth performance, nutrient digestibility, carcass traits, antioxidant properties, and ammonia production in broilers. J. Appl. Poult. Res. , 22: 904-912.

Khalil, A. F.; Elkatry, H. O. and El Mehairy, H. F., 2015. Protective effect of peppermint and parsley leaves oils against hepatotoxicity on experimental rats. Ann. Agric. Sci., 60: 353-359.

Lachowicz, K. J.; Jones, G. P.; Briggs, D. R.; Bienvenu, F. E.; Palmer, M. V.; Mishra, V. and Hunter, M. M., 1997.Characteristics of Plants and Plant Extracts from Five Varieties of Basil (Ocimumbasilicum L.) Grown in Australia. Journal Of Agricultural And Food Chemistry,45(7):26602665.

Lee M. T.; Lin, W. C.; Yu, B. and Lee ,TT.,2017 .Antioxidant capacity of phytochemicals and their potential effects on oxidative status in animals - A review ,Asian-Australas J. Anim Sci. 30(3): 299-308.

Leicester, RJ.; Hunt, RH., 1982.Peppermint oil to reduce colonic spasm during endoscopy. Lancet, 2: 989, [PubMed] [Google Scholar]. 
Liu, J.; Burdette, J.; Sun, Y.; Deng, S.; Schlecht, S. and Zheng, W., et al., 2004. Isolation oflinoleic acid as an estrogenic compound from the fruits of Vitex agnus-castusL (chaste-berry). Phytomedicine; 11:18e23.

Loch, EG.; Selle, H. and Boblitz, N., 2000. Treatment of premenstrual syndrome with a phytopharmaceutical formulation containing Vitex agnus castus. $J$ Womens Health Gend Based Med; 9:315-20.

Mashaly, M.M.; Hendricks, G.L.; Kalama, M.A.; Gehad, A.E.; Abbas, A.O. and Patterson, P.H., 2004. Effect of heat stress on production parameters and immune responses of commercial laying hens. Poult. Sci., 83, 889894.

Mehri, M.; Sabaghi, V. and Bagherzadeh-Kasmani, F., 2015. Mentha piperita (peppermint) in growing Japanese quails diet: Performance, carcass attributes, morphology and microbial populations of intestine. Anim .Feed Sci., Technol., 207: 104-111.

Moreno, FN.; Campos-Shimada, LB.; da Costa, SC.; Garcia, RF.; Cecchini, AL. and Natali, MR., 2015.Vitex agnus-castus L. (Verbenaceae) improves the liver lipid metabolism and redox state of ovariectomized rats. Evid Based Complement Alternat Med; 2015:212378.

National Research Council (NRC), 1977.Nutrients Requirements Of Rabbit. 2nd rev. ed. Washington. D.C. National Academy Press.

Nishino, T.; Tagaito, Y. and Sakurai, Y., 1997. Nasal inhalation of 1-menthol reduces respiratory discomfort associated with loaded breathing. Am. J. Respir. Crit. Care Med., 156: 309-313.

Ocak, N.;Erener, G.; Burak, Ak., F.; Sungu, M.; Altop, A. and Ozmen, A., 2008. Performance of broilers fed diets supplemented with dry peppermint (Mentha piperita L.) or thyme (Thymus vulgaris L.) leaves as growthpromoter source. Czech J. Anim. Sci. 53 (4), 169-175) of basil (Ocimum basilicum L.) grown in Australia. J. Agric. Food Chem., 45: 2660-2665.

Özlem, S.; Aslantürk and Tülay, A, Ç., 2013 Antioxidant activity and anticancer effect of Vitex agnus-castus L. (Verbenaceae) seed extracts on MCF-7 breast cancer cells. International Journal of Cytology, Cytosystematics and Cytogenetics, Volume 66, Issue 3, 257-267 
Pramila, D.; Xavier, R.; Marimuthu, K.; Kathiresan, S.; Khoo, M.; Senthilkumar, M.; Sathya, K. and Sreeramanan, S., 2012. Phytochemical analysis and antimicrobial potential of methanolic leaf extract of peppermint (Mentha piperita: Lamiaceae). J. Med. Plant Res., 6: 331-335.

Pudpila, U.; Khempaka, S.; Molee, W. and Hormta, C., 2011. Comparison of distillation methods of Mentha cordifoliaOpiz. Essential oil on antibacterial activity for application use in animal feeds. J. Agric. Sci. Technol. A, 1: 13361340.

Regiane, G.O.; Vanessa, F.S. A.; Carlos, E. C. ; Maria, G.M. S.; Anderson, C. G. ; Geone, M. C. ; Carlos ,H.G. M.; Renata, T.; Eliane ,O. S. and Antônio, E.M. C., 2017.Chemical Composition and Antibacterial Activity of the Essential Oil of Vitex agnus-castus L. (Lamiaceae),Annals of the Brazilian Academy of Sciences, 89(4): 2825-2832

Robert, J.; Edens, F.W. and Ferket, P.R., 2003. The effects of selenium supplementation on performance and antioxidant enzyme activity in broiler chicken. MS Thesis. North CarolinaState Univ., USA.

Sabrin, A.M.; Hasan, S. Z.; Soliman, M. Z.; Mohamed, H. A.; and Bothina, M .El., 2019. Growth performance, carcass traits, immune response and antioxidant status of growing rabbits supplemented with peppermint and basil essential oils.Egypt. Poult. Sci., Vol. (39) (I): 61-79)

Sarikurkcu, C.;Arisoy, K.; Tepe, B.;Cakir, A.;Abali, G. and Mete, E., 2009 .Studies on the antioxidant activity of essential oil and different solvent extracts of Vitex agnus-castus L. Fruits from Turkey. Food Chem Toxicol; 47:2479-83.

SAS, Institute., 2002. Sas/ Stat User's Guide Statistics. SAS Institute INC., Cary, NC, USA.

Schmidt, E.; Bail, S.; Buchbauer, G.; Stoilova, I.; Atanasova, T.; Stoyanova, A.; Krastanov, A.and Jirovetz, L., 2009 .Chemical composition, olfactory evaluation and antioxidant effects of essential oil from Mentha x piperita. Nat. Prod. Commun., 4, 1107-1112. [PubMed]

Teeter R.G.; Smith, M.O.; Owens, F.N. and Arp, S.C., 1985. Chronic heat stress and respiratory alkalosis: Occurrence and treatment in broiler chicks. Poult. Sci., 64, 1060-1064. 
Van Die, MD.; Burger, HG.; Teed, HJ. And Bon, KM., 2013.Vitex Agnus extracts for female reproductive disorders: a systematic review of clinical for female reproductive disorders: a systematic review of clinical trials. Planta Med; 79:562e75.

\section{الأداء الإنتاجى و الفسيولوجي للأراتب النامية متاثرا باضافة زيت النغناع

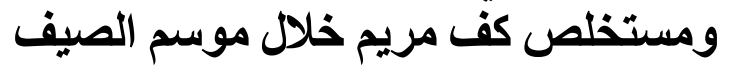

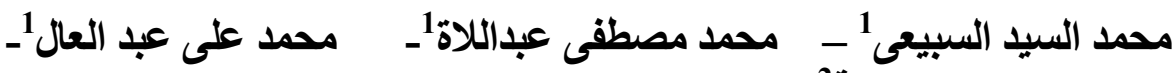 ايمن معوض خليفة

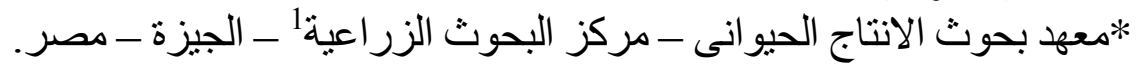

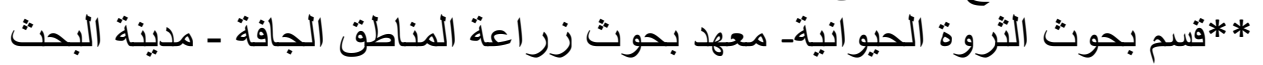 العلمي و التطبيقات التكنولوجية ـ الإسكندرية- مصر فئه}

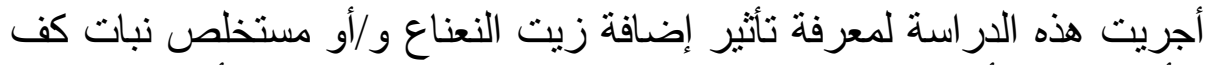
مريم على أداء النمو للأر انب النامية خلال موسم الصيف. تم تقية

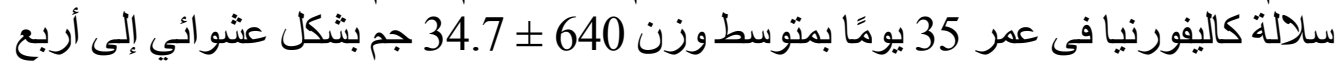

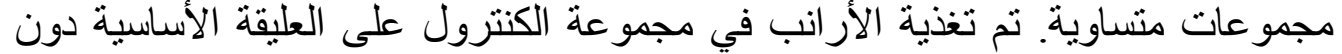
إضافات (المجموعة 1). تم تغذية المجموعات الثانية و الثالثة و الر ابعة على العليقة الأساسية

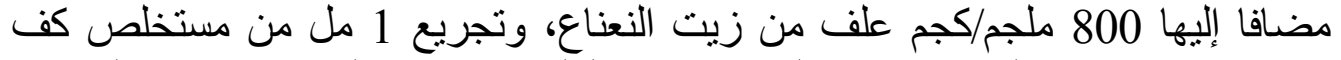

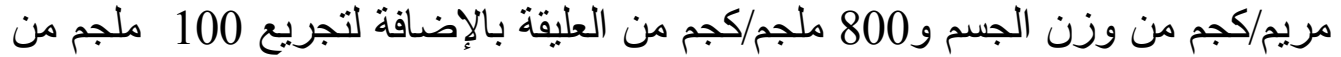

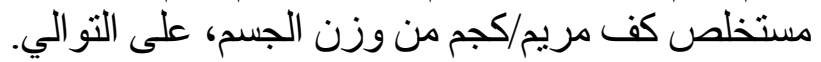
ويمكن تلخيص النتائج على النحو التالي: من وني:

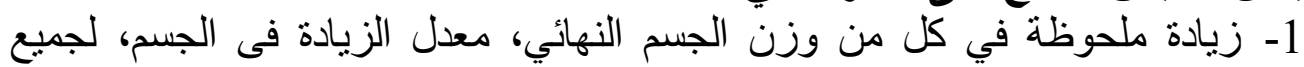

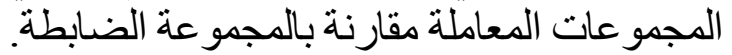

2- ليس هنالك أى تأثثر معنوى على كمية الغذاء المأكول، بينما تحسن معدل التحويل

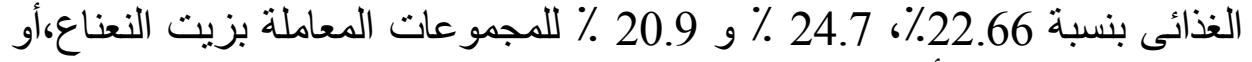
مستخلص كف مريم أو خليطهما، على التو الي مقارنة بالمجمو عة الضابطة. 


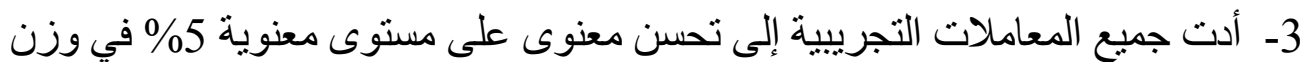

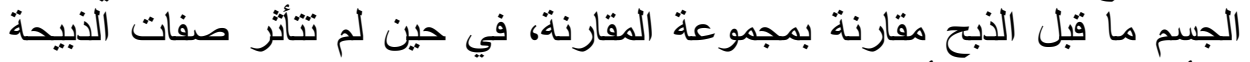
و الأجز اء الصالحة للأكل إحصائيا.

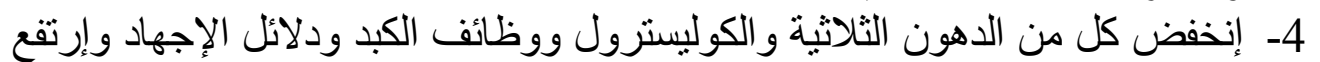
مستوى السعة الكلية لمضادات الأكسدة بشكل كبير للمجمو عات المعاملة مقارنة مع مجمو عة الكنترول. 5- لوحظت زيادة IgG لجميع المجمو عات المعاملة مقارنةً بمجمو عة الكنترول ، بينما لم يتأثز IgM إحسائيًا. التوصية : استخدام زيت النعناع ومستخلص كف مريم يمكن أن يؤدى لتحسن أداء النمو

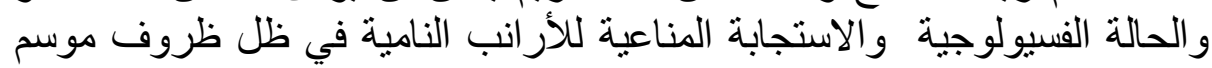
الصيف. 